\title{
Reconsidering the Geddesian Concepts of Community and Space through the Paradigm of Smart Cities
}

\author{
Chiara Garau *, Paola Zamperlin and Ginevra Balletto \\ Department of Civil and Environmental Engineering and Architecture, DICAAR, University of Cagliari, \\ via Marengo, 3, Cagliari 09123, Italy; p.zamperlin@gmail.com (P.Z.); balletto@unica.it (G.B.) \\ * Correspondence: cgarau@unica.it; Tel.: +39-070-675-5565; Fax: +39-070-675-5521
}

Academic Editor: Nicos Komninos

Received: 21 July 2016; Accepted: 23 September 2016; Published: 30 September 2016

\begin{abstract}
The 100th anniversary of Geddes' book "Cities in Evolution" has just passed, and the authors of this paper present a contribution towards understanding "how" Geddes might address the paradigm of the "smart city". Geddesian concepts have greatly revolutionized the design and building of modern cities around the world. As a botanist and a scientist, Geddes incorporated the concept of the appearance of gardens when designing towns. His success in pioneering the planning of his city of residence in Scotland inspired further involvement in designing towns and the renovation of old structures and buildings. His concepts regarding the planning and development of towns and cities have created a foundation of interest in research, professionalism, and educational development. This study analyses the concepts of space, communities, and smart cities, and repositions Geddesian ideas in contemporary learning strategies in relation to the wider political spectrum associated with the paradigm of smart cities. The authors explore the relevance of his thoughts and perspectives in the current design environment geared towards the creation of smart cities. The study also evaluates the challenges of developing smart cities in relation to Patrick Geddes's ideas.
\end{abstract}

Keywords: Patrick Geddes; community; urban planning; smart cities

\section{Introduction}

Cities reflect the traces of time, and are the outcome of a series of evolving mechanisms that influence their design, organisation, and planning. According to Di Biagi, the process of critically rereading planners of the past can be a fruitful endeavour, as "watching them from far away, in the light of the time elapsed from their writing and from the initial reception of the scientific community-may be useful [...] to a deeper understanding of culture and contemporary cities, avoiding, at the same time, the tyranny of the moment" [1]. This paper examines the legacy of Patrick Geddes in an attempt to give greater legitimacy to communities and modern cities that are increasingly motivated to becoming "smart". Geddes has many legacies; for example, his skills as a professor and for his sensitivity towards mixed communities [2,3]; for his survey techniques used in urban and rural planning [4]; for his incredible pioneering insights and advances for the practice of urban planning [2,3,5,6]; and for his ability to recognise the importance of The Garden City movement by being one of its first supporters [7]. This paper specifically focuses on Geddes' contribution to the concepts of space, community, and relations with technology.

A century ago, Patrick Geddes demonstrated great interest in cities and their sense of identity. A key example is the restoration and transformation of the Outlook Tower in Edinburgh, where he transformed the "Camera Obscura \& World of Illusions" building into a "place of outlook and a type-museum as a key to a better understanding of Edinburgh and its region, but also to help people 
get a clear idea of its relation to the world at large" [8]. As a Scottish botanist, biologist, urban planner, and reformist, Geddes was probably the first person to establish an explicit link between space and society in a prophetic way [9].

Currently, development planners recognise the city as an ecosystem with a "nervous system" made up of networks (due to globalisation), relationships (linked to local communities), and regulations (related to urban planning tools aimed at appropriate land use). The interrelationship of these factors is also contemplated alongside the adoption of smart strategies and synergies that, thanks to the "internet of things", create prospects of exogenous development that considers the person (with their endogenous effects) and the community (with its needs) as a focal point. This is the real smart revolution that is presently taking place. On one side, there is the city and its elements that exist in competitive global scenarios. On the other, there is enhancement of the community, with its traditions and its identity, and the interpretation of the needs and collective motivations from the bottom need to be more coherently matched to the local reality [10].

Geddes understood the importance of the awareness of identity and tradition, which was justified in the local context. A century later, and despite contextualizing Geddes in the intellectual milieu of his time [11], the broader academic field realizes how relevant his thoughts and his actions still are. Although we have progressed, we can and we have to improve to be able to place man and his needs as a focal point in urban analysis, pursuing the important goal that relates to the smart city with the identity and traditions of the settled community. Geddes demonstrated the value of community involvement in influencing the development of urban cities [12]. Geddes' concept of using the features of the natural world in developing cities could also be valuable in developing smart cities [13]. Governments should promote individual participation by directly investing in technologies and ventures that are likely to enhance the achievement and development of smart cities. In fact, today, a strong correlation exists between participation and the smart city; the literature converges on the confirmation that technological innovation is necessarily combined with social innovation $[10,14]$.

However, having noted this, the management of a "return" to the local level is fundamentally different. Contemporary management requires other forms of government that are, more participative, flexible, and attentive to environmental isues in line with the global city and its systems $[15,16]$. This requires reflecting on the city, the community, a community-based approach, various forms of local representation, and new tools resulting from the digital era typically related to smart city design, in order to increase the sense of belonging felt by citizens to their local realities and enhance loyalty to the institutions [14,17-19]. The application of Geddes' ideology regarding the concept of planning and the design of cities is significant when considering the planning and development of smart cities.

Based on these premises, the purpose of this article is to retrace Geddes' conceptualisation of space and community, and in doing so, highlight the many similarities with the current "smart city" approach. Technologies have evolved, spaces are dilated, and in spite of globalisation, the community has returned as the keystone of every social, urban, and political process. The community remarkably influences the development of the contemporary city so extensively that it often escapes the classical models of analysis and design. It is, however, where the core of Geddes' approach has found a consistent application.

This paper is organised into three sections. First, the authors focus on the evolution of the concepts of space and community, starting from Geddes and determining correlations with the smart cities approach. Second, we analyse how the design of urban space has ensured the sustained maintenance of its features over time. We specifically discuss a continual fascination felt towards the development of the new "smart" rules (fast times of globalisation, GBytes, Internet of Things, open data). Furthermore, we explore how the "parametric" rules that govern land use and social and environmental sustainability are used for the purpose of stemming competitiveness rather than as a new model of development.

This is not the case for citizenship, which instead has had sensitive transformations over time. An examination of the ideas of citizenship and the social status of policy developed by the metaphysical British idealists (which includes Geddes) is therefore required. The third section develops the concepts 
presented earlier and compares them with the problems and possible solutions identified in today's paradigm of smart cities. The paper concludes by considering the assumptions of Geddes' work for the smart city approach in terms of the concepts of space and community. This also emerges through an analysis of different projects in Italy that have adopted Geddes' approach and are simultaneously considered as "smart", as they are part of the collective of an Italian smart cities platform [20].

\section{Space and Community: Evolving Concepts}

In 1970, Peter Green analysed the urban planning theories of Geddes and emphasised the strong relations formed between places and the settled community when a major change was promoted. This was due to the characteristics of the community, its morphology, and its involvement, which were studied and explored before the commencement of planning and design of the city [7].

According to Gianluca Cristoforetti [10] and Luigi Mazza [21] (to whom we particularly refer in this paper), the relation between places and communities did not have, over time, a single interpretation in the scientific community.

However, a common convergence can be identified with the concept of membership in a political and civil community. On the one hand, some scholars consider the community as a part of a wider process of restructuring state functions. Within this, individuals and social groups have a greater role to play in this process than in the past, especially on issues of welfare $[22,23]$. On the other hand, this membership expresses political rights and activities, circumscribed in a place-based (and virtual) space where members of the political and civil community are engaged [24-26].

This perspective identifies a social process, and forms of belonging, practices, experiences, and activities that lead to a project of citizenship. Citizenship itself is approached and anchored to the government of the territory, specifically to those political processes that go beyond the execution and monitoring of decisions regarding the use of urban space. In order to offer a comprehensive understanding of this relationship, we analyse the concepts of community and space and examine them in terms of the similarities found between Geddes' perspective and the paradigm of smart cities. In doing so, we refer to a dimension not fixed in space and time by retracing the thoughts of key historical figures and eras. This is done in order to understand how and why the organisation of urban space has sustainably maintained its features and is largely unchanged over time, despite the fact that rights and awareness of citizenship have significantly changed over the same period.

The Concepts of Community and Citizenship Developed by Geddes and the Strong Correlations Found with the Smart City Approach

Based on the principles described above, the aims of a project of citizenship were quite clear to Patrick Geddes, and these were later revived by Henri Lefebvre, before being consolidated by Thomas Marshall [21]. Although they had important insights, recognised as such by their contemporaries [27,28], these perspectives infrequently disappeared and returned [29]. In fact, Geddes considered citizenship within a set of factors that were constantly evolving [12]. Furthermore, Geddes' logistic approach regarding actualisation (namely modelling, demarcation, and realisation) embodies a form of the ethical space of self-regulating civic life.

Geddes' ideas gradually developed as major changes were occurring in line with new political, economic, and social cultures, emerging as the basis of contemporary culture. The industrial revolution affected not only the theoretical and cultural fields, but also philosophical and political ideologies. This led to the expansion of more social, political, and civil rights. British idealists promoted the notion of granting every citizen the minimum conditions necessary for health, education, work, and living - an idea that would be taken up by reformers and urban planners [21]. In particular, Geddes argued that these guarantees could only be ensured by understanding the complexity of modern urban life through the correct interpretation of local culture and identity, social engagement, and national identity [7]. According to Rubin, Geddes adopted this philosophy in his projects, combining modern techniques and the retention of local culture [7]. 
Nearly fifty years after Geddes, Henri Lefebvre was perhaps the first person to identify the role of space in the construction and reconstruction of citizenship. He also drew distinctions between national (and international) and "local" citizenship [29]. By way of contrast, Marshall [30] advocated the topic of citizenship as a social issue in contemporary society. These historical references are important because they indicate decisive stages in the evolution of citizenship. According to Maurizio Ferrera, "the social components of citizenship have a value as important as that of its civil and political components", and decisions on rights regarding the forms and substance of the urban space are defined, depending on how it is interpreted [31].

Mobility, economy, governance, environment, living, and people are the six pillars in contemporary communities identified by Giffinger et al. [17] as being crucial for "smartness". In other words, the smart community is a complete ecosystem in which the coexistence of a variety of factors (that will inevitably affect the six pillars mentioned above) needs to be addressed in an integrated way in order to create a shared vision of the future. On the one hand, today's communities appear as accelerators of processes that lead to the transition of new needs (and therefore new models of development), and on the other hand, they appear to be aggregators, regardless of the (real or virtual) place in which they interact. The essence of Information and Communication Technologies (ICT) is to support different activities aimed at improving urban development and enhancing the way that people engage in carrying out their activities [32]. This conceptualisation of a community, according to Batty [33], refers to a system that enhances the exchange of information and creates aggregation among people. While the information exchange process may entail increasing the connection between individuals, the concept is also applied in explaining the exchange of information between intelligent interceptive points. According to Stratigea [34], this refers to the fact that the smart city is an integration of different technological and project development aspects that are important in achieving a modernized urban system. From these two interpretations of the community concerning the smart city, the concept should emphasize the value of social inclusion and involvement of the community. Importantly, these communities are also currently virtual, and in light of the smart city, they recreate urban communities in novel spaces and can support the collaboration between government and citizens. This human smart cities approach integrates digital technologies with the living lab methodology [35]. In this space, common interests and needs can be identified and common solutions can be co-designed in order to give a new sense of belonging and identity to citizens [35]. However, it is important to emphasize that today's communities evade the classical models of analysis and urban design because they exist with a multiplicity of factors and associated needs [10].

\section{The Concept of Space and Its Urban Government}

Today, smart cities are created on the foundation of sustainable growth and development. Smart cities aim to effectively utilise space in a manner that ensures that the whole system (or in Geddes' terms, an organism [12]) is maintained in the long term [36]. Efficiencies in smart cities are generated from an integrated planning process that is also oriented to increase population density in places where public transport is easily accessible [37]. Technology in smart cities is currently moving towards the internet of things. As cities gear toward a global market and culture, technology supports and simplifies access to services. In particular, this includes the automation of key elements, such as transport, communication, and trade. This reflects the fact that one of the most significant aspects of technology in smart cities is the use of intelligent automated infrastructure [38].

However, if the community and technology have changed significantly over time because they have suffered from great political and cultural shifts, this does hold with regard to spatial planning in the nineteenth century [39]. In fact, spatial planning maintains very similar characteristics of spatial control as a tool for social, economic, and physical control. Even as a technical tool, spatial planning maintains the basic features of ancient and modern zoning, although, the second half of the twentieth century saw the introduction of new procedures and operational techniques. It is not possible to locate symmetry between changes in the idea of citizenship and the transformation of place-based 
government processes [40]. This is because citizenship has a theoretical and political foundation, while the territorial government essentially has a political and practical foundation. The government of a territory can be considered as a political force that intervenes, even unknowingly, on civil, political, and social rights, in a positive or negative way [41].

The technical choices of territorial government were often, if not always, at the service of a political program for the community. From this point of view, a direct relation between the idea of citizenship and place-based government would be occasionally recognised [42]. For instance, Italy has been waiting since 1942 for a reform to the national law No. 1150 in the field of urban planning. Recent proposals [43] presented during the last legislature session (and the newest proposals under the governance of Minister Lupi) have settings that analyse the city through standards and restrictions, in the relationship of public space with the settled community, with the private initiative, and with the landscape.

At the beginning of the twentieth century, Geddes demonstrated the unique relations between place-based government and citizenship. His approach is an amalgamation of an evolutionary model that presents political and social concerns as features belonging to British idealism. Geddes proposed a more organised and empathetic abstract spatial social ideology [9]. In his book, Cities in Evolution [12], Geddes highlights the inherent fact that residents of cities had all but forgotten the history of their own city. Geddes believed that the only way inhabitants could understand the complexities of their "city as an organism" was to understand its history. He believed that space is a crucial element of the city as an organism, and its use is vital to the health of that organism. At the time, Geddes was writing in the context of the nineteenth century experience where most cities had been overtaken by economic and technological development. Motorization had brought considerable prospects after its discovery. However, this soon became the source of major obstacles in the modern-day city. Nevertheless, Geddes believed that technology reaches a point where it achieves a given level of complexity and becomes an autonomous variable, growing and expanding into all aspects of life [44], and becomes dependent so as to reduce the social relations at the base of the concept of community [45].

To Geddes, a city is an organism, as opposed to a mechanical system [46], made of complex and intricate processes that keep it alive. In his opinion, a city lives as a result of the people residing within it, and it is only when people develop a communal mind-set that they are able to appreciate its value. Through Geddes' actions, he inspired and mobilized his neighbours in James Court toward communal action. Community cohesion is an integral aspect of a sustainable and modern city. The absence of such cohesion leads to social problems that hinder significant progress [47].

Therefore, Geddes does not propose a single model of urban space, but advocated rules in order to make interventions in urban and planning transformation. As required by a developmental perspective, these interventions are underpinned by the theme of historical continuity and space. Geddes expanded the reference space from the house, to the garden, and to the region. This expansion was accompanied by a patronising attempt to engage the community, which recognises a form of the right to control and contribute to urban and place-based transformations [48]. This transformation of spatial planning was realised, in particular, by the contribution of Abercrombie, with the Greater London Plan [49]. The plan was drafted in a political climate that prepared for the construction of the welfare state and anticipated the spatial implications of the idea of social citizenship (although, Abercrombie does not explicitly refer to any form of citizenship). The idea of social citizenship, developed by Thomas Marshall in the first half of the twentieth century, becomes a motivation and justification of the spatial standards developed by Abercrombie, which intended to exercise a particular influence on the culture of place-based government that has persisted to the present day [21].

\subsection{The Interrelation between Community and Space}

The relation between place-based government and citizenship has never been unilateral because place-based government produces citizenship in a conscious or unconscious manner, and in turn, is motivated by citizenship. The circular relations that clarify the nature of place-based government 
are traditionally overshadowed by the production of other physical and social effects, and not directly by citizenship $[21,29,42,50]$.

At the end of the 1960s, Lefebvre reflected on the further transformation of the relations between place-based government and citizenship. His hypothesis was that an urban revolution could reform capitalist culture. His idea of "the right to the city" [51] has been accepted in several European cities, thus encouraging popular claims of living in the city since the 1970s [52]. Lefebvre's ideas demand greater control over urban master plans and urban projects in order to offer housing and social services that improve the conditions of urban life. In practice and in many cases, this translates into a bureaucratic and regulatory rigidity that produces more criticism of and disaffections with place-based government. In many contexts, the reaction to this rigidity is urban speculation, encouraged by the general climate of strong individualism, power of profit, and carelessness of the city as a common good [53]. Lefebvre's hope of social and urban revolution that would lead to the consumerism and capitalist production was lost in continental Europe with the rise of neo-liberal Anglo-Saxon culture and the overwhelming development of globalisation. The ideas of welfare and citizenship are in crisis, even though as a reaction in the 1990s, citizenship returned to being a basic topic of study and debate [54].

The study of social rights focuses attention on a local form of citizenship, though it is increasingly clear that the difference between civil and political rights is formally achievable with institutional reforms [55]. These represent a system of opportunities and services whose production requires a redistribution of income of a political and institutional nature. In this framework, the choices of place-based government result in more opportunities to support speculation or to defend local spaces and environment. These choices are focused primarily on preventing changes that could alter the balance of political, social, and economic locations, but are sometimes made to facilitate and cover urban speculation. Social rights seek a balance that is not always easy between conservation and transformation, and in many cases, the process is corrupted [56].

The lack of a shared idea of citizenship also results in a decline of a sense of civic duty that makes it possible to share projects and measure collective interest [57]. Individualistic consumerism, indifferent if not contrary to the collective projects, leads to a spread of a Not in My Back Yard (NIMBY) attitude that paralyzes many public interventions and follows different spatial patterns. The grave financial crisis of the century, which is still felt today, has at least partially suppressed the importance of the relation between citizenship and spatial ordering, because it has weakened both. In addition, new technologies have introduced digital communities that harmonise with places in a radically different way. Mitchell [58-60] and Castells [61-63] have examined the important sociological effects of a future dominated by ICT.

The transformations that have led to virtual communities did not happen in a sudden or catastrophic way, but rather they developed incrementally. It is interesting to study this process, particularly with regard to aspects related to environmental, social, and economic sustainability. In fact, the sensitivity of these issues now require different choices compared to them of the period of the economic boom of the industrial era. On the one hand, the dynamics of globalisation led to a greater understanding of the local environment and landscape related to the sustainable use of its resources. On the other hand, globalisation has created growing challenges to the competitiveness of territories, especially those on the margins of global development.

At this time of general crisis, restoring and strengthening the ideas of (virtual and real) citizenship and place-based government is necessary. However, the scientific and political influence of this perspective and ideal is still not strong enough. Retracing the thoughts of Geddes might be useful for this purpose, because as Meller [64] observes: the rise of science and technology had helped to create both the worst conditions known to men, and also the power to control life and environment to an unprecedented extent. In this sense, the thoughts of Geddes are clearly relevant. The ability to respond to change is a key factor for Geddes, and it is an applicable ideal for smart cities. In fact, the adjective 
"smart" has always reflected the desire to indicate an "evolutional" state of a specific issue for the latest developments of technological innovation [65].

Although scholars do not unanimously define what constitutes a smart city $[14,17,18,66-68]$, in every attempt for definition, there is a constant element: the interrelation between the physical and virtual space. The principal aspect that characterises the smart city approach is the capacity of design to bind old traditions with new tools, new propensities for listening, and new creativity (the most significant platforms that bind the old with the new ones are in Scandinavia [69], Germany [70] and Italy $[71,72])$.

These factors, until now, have been addressed separately within a single frame of "the smart" combination of the six principal pillars (mobility, economy, governance, environment, living, and people) [17]. In the physical space of a smart city, technology inclusively supports the growth of social capital and enables the development of a functional system. This system allows for the simultaneous realisation of a number of activities, encouraging a reuse of space and time that help maximize the levels of liveability of the urban system [73]. That is, this urban structuring leads to the responsible use of resources, adopting behaviour-based practices of recycling and reuse, energy savings, mitigation, and general adaptation to change ([73], p. 51).

\subsection{A Critical Perspective and Analysis on the Concepts of Space, Community, and Smart Cities}

This brief overview of space and community shows how these concepts have evolved over time. Geddes [12], as a social evolutionist, shared his passion for the city with his contemporaries by developing it in all its formulations. His perspective as a naturalist led him to look at the city of the present and of the future. For Geddes, the city is a common good in evolution, understood in terms of its individual buildings and the growth of its population. This is achieved by scientific observation, a profound knowledge of history, and a regional balance, all of which are undertaken through the understanding that relations between the city and the surrounding agricultural economy are symbiotic [12]. His work foreshadowed the principle of sustainability declared by the Brundtland Commission (1987) and the Rio conference (1992). Sustainable development was subsequently perceived as a combination of environmental (ecological), economic, and social dimensions [74-77].

With the benefit of hindsight, we can see that many urban projects failed. They did not take into account the fact that their utopian proposals could only be realized if they evaluated the effects on society, the economy, and the coherence of the proposed development of the city with different levels of government. It is almost impossible for the utopian ideal of the city, illuminated by the ideas of great architects, to become a reality without an evaluation of the financial and structural issues, trends of the times, and especially the responsiveness of the institutions concerned [78].

Geddes also considers citizenship as an active part of building the civitas. In City Development [79], he distinguishes between a town and a city. The town is devoid of consciousness; it is a place of production and consumption and determines human behaviour. A town can become a city due to the convergence of traditional and innovative knowledge. The distinction between a town and a city is further deepened in Civics, where Geddes also introduces the concept of the fact of life [80]. This notation is captured in a diagram that illustrates the evolutionary process of every urban and regional community as a spiral process, which can be progressive or regressive, depending on individual and collective behaviour. These principles fit well with today's paradigm of smart cities, even if today the distinction between a city and a town is commonly a regulatory issue [10]. Geddes's town is a city that is unable to become smart, and Geddes's city can become a town again if does not continue to evolve, because a town is a place that cannot adapt to change. In relation to these concepts, current cities should not aspire to an ideal value of smartness that is standardized for everyone (as the current literature on smart cities requires), but rather, it should aim for the relative value, which takes into account the specific allocations of individual contexts and the identity of its inhabitants. 
Scientific debate is currently circulating and the European Union (EU) has expressed great interest in the issue of smartness. It constitutes one of the cornerstones of European growth and the associated planning strategy. The EU has undertaken and will continue to support [81-87] cities and regions that adopt innovation to combine "soft" infrastructure-innovation, creativity, knowledge, users-with "smart" infrastructure (new technologies) through enlightened and smart governance [14].

This model of the smart city and Geddes' ideals contend that society evolves only if individualism and utilitarianism are rejected in the pursuit of projects for the common good. For both, citizenship is fundamental to procedural practice, but the outcomes of this practice are equally important. In the model of a smart city, outcomes are constantly analysed, and each city is monitored, evaluated, and benchmarked on the basis of its performance [14,17,88-97]. Good architecture, an efficient transport system, compact and sustainable urban morphologies, and good governance can build a proper urban society. This convergence of ideas highlights the fact that the evolutionary perspective of Geddes has remained relevant over the last century, despite the changing idea of citizenship and the gradual increase seen in the number and quality of individual rights that are currently recognized. In fact, the ordering of space has seen its characteristics remaining largely unchanged over time.

\section{Repositioning Geddes' Ideas in Contemporary Problems Faced by Smart Cities}

The integration of Geddes' ideas in city planning and development is likely to enhance the overall outcomes of urban development. One of the core principles in Geddes' city planning is the concept of cities being seen as whole organisms. This principle is based on the idea that cities require green open spaces to ensure sustainability of the processes and functions of the different aspects of city life. This concept is also important in the smart cities paradigm [98]. Geddes highlighted the importance of effectively using an interdisciplinary approach in developing knowledge to create useful synergies and connections between the different disciplines and subject areas. Although smart cities offer a wide variety of services and amenities, they are characterized by a number of problems and issues related to space, community, and technology, as they have been conceptually postulated by Geddes and described in the previous section.

Italy's national, regional, local institutions, and communities have catalogued publicly funded projects in the Italiansmartcity platform [20]. This platform was created to assess the smart performance of Italian cities, subdividing the smartness into eight sectors: environment, energy, economy, people, living, mobility, government, and planning. Table 1 shows the projects that have been initiated, are ongoing, or have been completed at the local level. The table also provides an assessment of these projects in relation to the ability to impact the three dimensions of sustainable development: (1) economic, or the ability to generate income and employment for the population, and to influence the territory's levels of economic growth; (2) social, meaning the ability to guarantee that human welfare conditions are equally distributed among all classes; and (3) environmental, meaning the ability to maintain the quality and continual availability of natural resources.

Table 1. Level of funding and numbers of municipalities involved in smart initiatives by sector (Adapted from the Italian Smart Cities platform. Accessed 10 July 2016).

\begin{tabular}{ccccccc}
\hline Sectors & Euro & Budget \% & $\begin{array}{c}\text { Project } \\
\text { Number }\end{array}$ & $\begin{array}{c}\text { Project } \\
\text { Number \% }\end{array}$ & $\begin{array}{c}\text { Municipalities } \\
\text { Involved }\end{array}$ & $\begin{array}{c}\text { Municipalities } \\
\text { Involved \% }\end{array}$ \\
\hline PLANNING & $€ 1,012,075,377$ & $27 \%$ & 103 & $8 \%$ & 45 & $28 \%$ \\
MOBILITY & $€ 820,513,992$ & $22 \%$ & 244 & $19 \%$ & 80 & $51 \%$ \\
ENERGY & $€ 642,492,459$ & $17 \%$ & 139 & $11 \%$ & 55 & $35 \%$ \\
ECONOMY & $€ 376,906,091$ & $10 \%$ & 114 & $9 \%$ & 53 & $34 \%$ \\
LIVING & $€ 283,099,247$ & $8 \%$ & 168 & $13 \%$ & 76 & $48 \%$ \\
ENVIRONMENT & $€ 289,981,711$ & $8 \%$ & 192 & $15 \%$ & 83 & $53 \%$ \\
PEOPLE & $€ 171,416,226$ & $5 \%$ & 182 & $14 \%$ & 58 & $37 \%$ \\
GOVERNMENT & $€ 113,673,883$ & $3 \%$ & 169 & $13 \%$ & 54 & $34 \%$ \\
TOTAL & $€ 3,713,591,164$ & $100 \%$ & 1312 & $100 \%$ & 158 & $100 \%$ \\
\hline
\end{tabular}


Table 1 shows the most financed sectors (planning (27\%), mobility (22\%), and energy (17\%)), while the most numerous projects fall within the following sectors: mobility (244 projects; representing 19\% of the total Italian projects), environment (192 projects; $15 \%$ ), and people (182 projects; $14 \%$ ).

As emphasized above, Patrick Geddes employed an interdisciplinary approach toward solving urban issues, and this interdisciplinary approach can be re-positioning in the current paradigm of smart cities. Namely, the current paradigm of smart cities is related to the concepts of space, community, and technology. In addition, urban settlements have to call into question their settlement model, because they are constantly changing and are characterised by overproduction, and they need to adopt the holistic thinking of Geddes, so as to produce "reuse, recycle, and creative" evolutionary developments [99]. These concerns specifically affect infrastructure, transport, planning regulation, and characteristics that apply to the city transversally, and as shown in Table 1, they are the most financed in Italy (mobility, planning, and energy).

\subsection{Aging Infrastructure}

In Italy, one of the biggest problems facing smart cities is infrastructure. Smart cities are founded on the concept of modernising infrastructure to sustain the needs of a modern population. This modernisation process is more difficult to enact in the historic centres, where legislation further slows the process. One critical challenge facing smart cities is the existence of old and outdated structures that are considerably costly to redevelop or rebuild. The actions that are designed in the modernisation of infrastructure therefore cover those initiatives that apply to urban contexts. Renewable energy sources (instruments that allow for efficient and district heating networks) and those interventions related to public lighting and intelligent building (public and private) are examples of this. As shown in Table 1, the amount of funding dedicated to the energy sector is significant: it is the third most funded sector in Italy, with a total budget of $€ 642,492,459$.

Old structures that lack smart city technology in their architecture continue to challenge the development of smart cities [100]. Geddes depicted this in his James Court project. After purchasing a row of houses in this slum area, he employed the idea of conservative surgery as opposed to the gridiron plan, and opted to weed out compromised structures and only retain good structures, which were then subsequently remodelled.

\subsection{Transportation Flow}

This sector is identified in Table 1 under Mobility, and is the second most funded sector in Italy with a total budget of $€ 810,482,997$. The Italian smart cities platform stresses that this sector raises the question of how to move people and goods, ensuring that service levels are progressively more efficient, and reducing the negative consequences that are simultaneously applied on citizens.

Transportation is an integral and essential part of the success, growth, and development of any given economy. Nevertheless, transportation accounts for high pollution and energy consumption [101]. In addition, the improvement, development, and management of transport infrastructure is usually realised at a great cost to the environment. With increasing population densities, effective planning and development of transportation systems is a considerable challenge. Smart cities rely heavily on the transportation system to allow for traffic flows between different areas of the city. In fact, a common goal is to reduce car traffic and get citizens to use public transport, bicycles, or walk. As such, they have to employ numerous transportation modes to realise full efficiency. Synchronising different modes of transport (road, rail, air, and water) is a considerable challenge. Cities have to develop systems that ensures nearly seamless traffic flow.

We can therefore distinguish two fields: city logistics and the mobility of people. The first can be understood as the process that optimises last mile logistics and the transportation activities of its private companies in urban areas. The second concerns the development of new environmentally friendly and sustainable mobility (pedestrian mobility, cycling mobility, shared mobility, and new solutions for local public transport) [37]. Transverse to the two areas are mobile information, pricing 
policies, toll and staging systems, research, and the effective integration of new alternative energy sources to oil in the specific field of mobility and transport.

\subsection{Planning Regulation}

The planning sector introduced in the Italian smart cities platform is well funded in Italy, with a total budget of $€ 1,017,105,455$ and with cross-cutting initiatives related to the planning and governance of the smart Italian city that are linked and characterised by choices and paths rather than heterogeneous application of the planning model.

Smart cities remain sustainable and functional, based on the theoretical ability to regulate almost all aspects of its existence and function. This includes urban responsibility in being able to attract people, businesses, and supportive communities to the city. It also includes the ability to implement concrete actions to ensure a new balance between rural areas, urban areas, and areas that can be urbanised, but also between the landscape and infrastructure. This can possibly be achieved through an elaborate regulatory system, that (for example) limits soil consumption, but especially by stimulating, encouraging, and rewarding the reuse of existing urban or planned areas. Many Italian projects in the planning sector have been carried out according to this logic. For example, consider the case of the Integrated Plan for Sustainable Urban Development in Florence, whose beneficiaries of the project are: public administration, residents, city users, and businesses. The project was launched in 2009 and has a committed budget of $€ 45,477,590.00$. Many cities and metropolitan areas try to attract prospective development companies through information conveyed on their websites and through synergies with the private sector [102]. Smart cities are faced with the challenge of attracting the right kind of investors. For example, the 2020TOGETHER project in Turin has initiated coordinated action between the regional, provincial, and municipal authorities, financial institutions, investors, and local companies in order to launch an investment program as part of the redevelopment of public buildings and public lighting, through public and private partnerships and third-party financing of the Energy Saving Company (ESCo). In order to effectively plan a smart city, city managers have to adopt an ecosystem approach, one that is organic and based on the main thoughts of Geddes, thus being guided by forward-looking visions that retain the traditions, rituals, and practices of the past.

Patrick Geddes employed an interdisciplinary approach toward solving the issue of planning modern and efficient cities. This interdisciplinary approach can also be useful in the governance of smart urbanism.

\section{Conclusions}

We conclude with a quote from Geddes in which he anticipates modern environmentalist principles [103], the importance of a community that is contextualised in its history, and especially the relationship between the concept of cities to the theory of evolution. He writes:

"The study of human evolution is not merely a retrospect of origins in the past [...]. Beyond the first question of Whence?-Whence have things come from? and the second, of How?-How do they live and work? - the evolutionist must ask a third. Not, as of old at best, What next?-as if anything might come; but rather Whither?-Whither away? For it is surely of the essence of the evolution concept [...] that is should not only inquire how this of today may have come out of yesterday, but be foreseeing and preparing for what the morrow is even now in its turn bringing towards birth." ([12], pp. 3-4).

Geddes believed that a city is an organism as opposed to a mechanical system. In the city, the community plays a key role, as it is in a continuous evolutionary process and is able to reinvent itself through strong integration with ecological sustainability, with land-use planning, and with transport management. Smart cities are essentially developed on the foundation of sustainable growth and development. Smart cities aim to effectively utilise space in a manner that ensures the whole system, as an organism, is sustained in the long term. The projects listed in the Italian smart cities platform show that Italy is following this movement. 
According to Khan [104], Geddes avoids setting up "the human individual as the master of the world, directing all material progress. Instead he shows how necessary it is for an individual or collective to be in cooperation with the invisible and the unseen for positive outcomes". Thus, in smart cities, human and social capital ("soft infrastructure") is linked to new technologies ("smart infrastructure") only if they are properly related to enlightened smart governance at work in smart communities [52]. A theme dear to Geddes is to strengthen the community by the development of its local capital through the decentralisation of the central government and the role of the planner. For Geddes, urban planning is a public activity rather than a set of rules [105]. On the other hand, man alone is "the master of the world", and a team effort, which when integrated efficiently with the territory and new technologies can ensure the efficient use of resources, maximizes the attractiveness of what is offered locally. In fact, Geddes was also a precursor of sharing communication, social, and urban processes [106].

This ideology is in line with most of the foundational aspects of smart cities. The cities of today employ knowledge from different sectors to develop an ideal model of smart cities. In them, the changes mainly result from enabling technology (broadband, sensors, software apps, open data, etc.) to support the "dynamic" city. In fact, the urban organism of Geddes was associated with a value correlated to the nature; the natural urban organism of today also has a technological value in support of the community and its quality of life.

According to Schaffers et al. [107] and Komminos [108], smart cities and technological infrastructure create changing cities in two ways. First, smart city solutions change the city itself, enable new ways of using the urban space, virtualizing activities and infrastructure, and optimizing energy, water, transport, and other utilities. Second, smart city applications change the innovation and decision making system of cities, offering online planning and city management, transparency, citizen engagement platforms, large data sets, urban awareness, and analytics.

For these reasons, the concept of a smart city is an abstract projection of a new common good. It comprises an advanced technological infrastructure that is capable of creating a dialogue between the city, the community, its inhabitants, and tangible and intangible objects. This generates intelligence, models of inclusion, rules of governability between the public and private sectors, new financial instruments, and regulated, transparent, and simplified actions on which government can formulate credible promises for the medium-long term. Thus, a smart city must evolve to adapt its threshold of smartness over time.

Both Geddes's model and the concept of a smart city comprise of a mix of different influences. It is an evolutionary model that merges the political and social concerns of the current time. Both paradigms do not propose a model of urban space, but set guidelines to improve the quality of urban and regional planning. Geddes expands the space of reference from the house, to the garden, and to the region, whereas the model of a smart city reduces the space of reference to the city from a global vision of networks. In both models, this is accompanied by the involvement of the population in which the right to control and contribute to urban and place-based transformations is recognised.

The comparison between Geddes's ideas and the model of smart cities highlights how relevant Geddesian ideas are in contemporary development and planning strategies [109].

Acknowledgments: This study is supported by the MIUR (Ministry of Education, Universities and Research (Italy) through a project entitled Governing the smart city: a governance-centred approach to Smart urbanism-GHOST (Project code: RBSI14FDPF; CUP Code: F22I15000070008) financed with the SIR (Scientific Independence of young Researchers) programme. We authorize the MIUR to reproduce and distribute reprints for Governmental purposes notwithstanding any copyright notation thereon. Any opinions, findings, and conclusions or recommendations expressed in this material are those of the authors and do not necessarily reflect the views of the MIUR.

Author Contributions: This paper is the result of the joint work of the authors. In particular, Section 4 has been jointly written by all the authors. Chiara Garau wrote Sections 1, 3 and 3.2; Ginevra Balletto wrote Sections 2 and 3.1; and Paola Zamperlin wrote Section 5. 
Conflicts of Interest: The authors declare no conflict of interest. The founding sponsors had no role in the design of the study; in the collection, analyses, or interpretation of data; in the writing of the manuscript, and in the decision to publish the results.

\section{References}

1. Di Biagi, P. A Cura di. I Classici Dell'Urbanistica Moderna; Donzelli Editore: Roma, Italy, 2009; p. viii.

2. Mairet, P. Introduction. In Pioneer of Sociology: The Life and Letters of Patrick Geddes; Lund Humphries: London, UK, 1957; pp. xvii-xx.

3. Halliday, R.J. The sociological movement, the sociological society, and the genesis of academic sociology in Britain. Sociol. Rev. 1968, 16, 377-398. [CrossRef]

4. Fleure, H.J. Patrick Geddes (1854-1932). Sociol. Rev. New Ser. 1953, 1, 5-13. [CrossRef]

5. Ashworth, W. The Genesis of Modern British Town Planning: A Study in Economic and Social History of the Nineteenth and Twentieth Centuries; Routledge \& Kegan Paul: London, UK, 1954.

6. Earley, J. Sorting in Patrick Geddes' Outlook Tower. Places 1991, 7, 64-71.

7. Rubin, N.H. The changing appreciation of Patrick Geddes: A case study in planning history. Plan. Perspect. 2009, 24, 349-366. [CrossRef]

8. Streich, B. Stadtplanung in der Wissensgesellschaft: Ein Handbuch; VS-Verlag: Wiesbaden, Germany, $2011 ;$ p. 44.

9. Osborne, T.; Rose, N. Spatial phenomenotechnics: Making space with Charles Booth and Patrick Geddes. Environ. Plan. D Soc. Space 2004, 22, 209-228. [CrossRef]

10. Cristoforetti, G. Smart City and Community-Based Planning; INU Edizioni srl: Roma, Italy, 2014.

11. Simmons, H.G. Patrick Geddes-Prophet without politics. Stud. Mod. Eur. Hist. Cult. 1976, 2, $159-191$.

12. Geddes, P. Cities in Evolution: An Introduction to the Town Planning Movement and to the Study of Civics; Williams \& Norgate: London, UK, 1915. Available online: https://archive.org/stream/ citiesinevolutio00gedduoft\#page/n9/mode/2up (accessed on 19 July 2016).

13. Parsons, K.C.; Schuyler, D. From Garden City to Green City: The Legacy of Ebenezer Howard; Johns Hopkins University Press: Baltimore, MD, USA, 2002.

14. Caragliu, A.; Del Bo, C.; Nijkamp, P. Smart cities in Europe. J. Urban Technol. 2011, 18, 65-82. [CrossRef]

15. Sassen, S. The Global City: New York, London, Tokyo; Princeton University Press: Princeton NJ, USA, 2001.

16. Calzada, I.; Cobo, C. Unplugging: Deconstructing the smart city. J. Urban Technol. 2015, 22, 23-43. [CrossRef]

17. Giffinger, R.; Fertner, C.; Kramar, H.; Kalasek, R.; Pichler-Milanović, N.; Meijers, E. Smart Cities: Ranking of European Medium-Sized Cities; Vienna University of Technology: Vienna, Austria, 2007.

18. Murgante, B.; Borruso, G. Cities and smartness: A critical analysis of opportunities and risks. In Proceedings of the International Conference on Computational Science and Its Applications, Ho Chi Minh City, Vietnam, 24-27 June 2013; Springer: Berlin/Heidelberg, Germany, 2013; pp. 630-642.

19. Garau, C. Smart paths for advanced management of cultural heritage. Reg. Stud. Reg. Sci. 2014, 1, $286-293$. [CrossRef]

20. La via Italiana Alle Comunità Intelligenti. Available online: http://italiansmartcity.it/ (assessed on 22 September 2016). (In Italian).

21. Mazza, L. State, citizenship, and common good: British idealists' influence on social philosophy and planning culture. City Territ. Archit. 2014, 1, 1-7. [CrossRef]

22. Holden, A.; Iveson, K. Designs on the urban: New Labour's urban renaissance and the spaces of citizenship. City 2003, 7, 57-72. [CrossRef]

23. Cochrane, A. Understanding Urban Policy: A Critical Approach; Blackwell: Oxford, UK, 2007.

24. Madden, D.J. City becoming world: Nancy, Lefebvre, and the global-urban imagination. Environ. Plan. Part D 2012, 30, 772-787. [CrossRef]

25. Putnam, R.D. Bowling Alone: The Collapse and Revival of American Community; Simon and Schuster: New York, NY, USA, 2001.

26. Putnam, R.D.; Feldstein, L.; Cohen, D.J. Better Together: Restoring the American Community; Simon and Schuster: New York, NY, USA, 2004.

27. Chapman, D. The common sense of Patrick Geddes. Town Ctry. Plan. 1945, 13, 161-181.

28. Pepler, G. Geddes' contribution to town planning. Town Plan. Rev. 1955, 26, 19-24. [CrossRef]

29. Mazza, L. La Città Come Progetto e Spazio Politico e di Rappresentazione; Educatt: Milano, Italy, 2012. 
30. Marshall, T.H. Citizenship and Social Class; Cambridge University press: Cambridge, UK, 1950; Volume 11, pp. 28-29.

31. Ferrera, M. Verso una cittadinanza sociale aperta. I nuovi confini del welfare nell'Unione Europea. Riv. Ital. Sci. Politica 2004, 34, 2.

32. Ferrara, R. The smart city and the green economy in Europe: A critical approach. Energies 2015, 8, 4724-4734. [CrossRef]

33. Batty, M. The New Science of Cities; Elsevier: London, UK, 2013.

34. Stratigea, A. The concept of "smart cities" towards community development? Netcom 2012, 26, 375-388. [CrossRef]

35. Sanseverino, E.R.; Sanseverino, R.R.; Vaccaro, V. Atlante Delle Smart City. Comunità Intelligenti Europee ed Asiatiche; Franco Angeli: Milano, Italy, 2015.

36. Batty, M.; Marshall, S. Centenary paper: The evolution of cities: Geddes, Abercrombie and the new physicalism. Town Plan. Rev. 2009, 80, 551-574. [CrossRef]

37. Sultana, S.; Weber, J. (Eds.) Minicars, Maglevs, and Mopeds: Modern Modes of Transportation around the World: Modern Modes of Transportation around the World; ABC-CLIO: Santa Barbara, CA, USA, 2016.

38. Gianni, F.; Divitini, M. Technology-enhanced Smart City Learning: A Systematic Mapping of the Literature. Interact. Des. Archit. J. 2016, 27, 28-43.

39. Gallent, N.; Ciaffi, D. Introduction. In Community Action and Planning: Contexts, Drivers and Outcomes; Gallent, N., Ciaffi, D., Eds.; Policy Press: Bristol, UK, 2016; pp. 3-19.

40. Alexander, E.R.; Mazza, L.; Moroni, S. Planning without plans? Nomocracy or teleocracy for social-spatial ordering. Prog. Plan. 2012, 77, 37-87. [CrossRef]

41. Adams, C.; Millard, P. The Evolution of State, People and Corporate Relationship in e-Government. In Proceedings of the 14th European Conference on e-Government: ECEG 2014, Brasov, Romania, 12-13 June 2014; Academic Conferences and Publishing International Limited: Sonning Common, UK, 2014; pp. 10-14.

42. Mazza, L. Geddes "politico": Vision, survey, citizenship. Territorio 2008, 45, 91-98.

43. The Most Recent Proposal Is the Draft Law of the Italian Institute of Urban Planning (Istituto Nazionale di Urbanistica-INU) on the Government of Territory. 2008. Available online: http:/ /www.inu.it/wp-content/ uploads/LGT_INU_finale.pdf (accessed on 21 September 2016).

44. Braham, W.W.; Hale, J.A.; Sadar, J.S. Rethinking Technology: A Reader in Architectural Theory; Routledge: New York, NY, USA, 2007; p. 53.

45. Adler, P.S.; Kwon, S.W. Social capital: Prospects for a new concept. Acad. Manag. Rev. 2002, 27, 17-40.

46. Geddes, P.; Ferreira, J.V.; Jha, S.S. The Outlook Tower: Essays on Urbanization in Memory of Patrick Geddes; Popular Prakashan: Bombay, India, 1976.

47. Sampson, R.J.; Morenoff, J.D.; Gannon-Rowley, T. Assessing "neighborhood effects": Social processes and new directions in research. Annu. Rev. Sociol. 2002, 28, 443-478. [CrossRef]

48. Jagadisan, S.; Fookes, T. Antecedents for the Ekistic Grid and the Anthropocosmos Model: A critical view of ekistic methodology. Ekistics 2006, 73, 265-276.

49. Abercrombie, P. Greater London Plan; University of London Press: London, UK, 1944.

50. Mazza, L. Riformatori morali e meccanici. Cittadinanza e controllo spaziale tra ottocento e novecento. In Le Frontiere Della Geografia. Testi, Dialoghi e Racconti per Giuseppe Dematteis; Aa, V., Ed.; Utet: Novara, Italy, 2009; pp. 293-331.

51. Lefebvre, H. The right to the city. In Writings on Cities; Kofman, E., Lebas, E., Eds.; Blackwell: Cambridge, MA, USA, 1995; pp. 63-184.

52. Garau, C. Perspectives on cultural and sustainable rural tourism in a smart region: The case study of Marmilla in Sardinia (Italy). Sustainability 2015, 7, 6412-6434. [CrossRef]

53. Salzano, E. Dualismo urbano. Città dei cittadini o città della rendita. QT2 Quad. Territ. 2011, 2, $143-153$.

54. Culpitt, I. Welfare and Citizenship: Beyond the Crisis of the Welfare State?; Sage Publications: London, UK, 1992.

55. La Bella, M. Cittadinanza locale e strumenti di accountability. In Questioni e Forme Della Cittadinanza; La Bella, M., Santoro, P., Eds.; Franco Angeli: Milano, Italy, 2011.

56. Sberna, S.; Vannucci, A. Corruzione e infiltrazioni criminali nel governo del territorio. In Città e Politiche in Tempo di Crisi; Fregolent, L., Savino, M., Eds.; Franco Angeli: Milano, Italy, 2014; pp. 195-235. 
57. Searing, D.D.; Conover, P.J.; Crewe, I. Citizenship in the age of liberalism. Parliam. Aff. 2003, 56, 634-651. [CrossRef]

58. Mitchell, W.J. City of Bits: Space, Place and the Infobahn; MIT Press: Cambridge, MA, USA, 1995.

59. Mitchell, W.J. E-Topia: Urban Life, Jim-But Not as We Know It; MIT Press: Cambridge, MA, USA, 1999.

60. Mitchell, W.J. Me ++: The Cyborg Self and the Networked City; MIT Press: Cambridge, MA, USA, 2003.

61. Castells, M. The Information Society and the Welfare State: The Finnish Model; Oxford UP: Oxford, UK, 2002.

62. Castells, M. The Network Society: A Cross-Cultural Perspective; Edward Edgar: Cheltenham, UK; Northampton, MA, USA, 2004.

63. Castells, M. The Network Society: From Knowledge to Policy; Center for Transatlantic Relations: Washington, DC, USA, 2006.

64. Meller, H.E. Cities and evolution: Patrick Geddes as an international prophet of town planning before 1914. In The Rise of Modern Urban Planning 1800-1914; Mansell: London, UK, 1980; p. 199.

65. Gil-Garcia, J.R.; Pardo, T.A.; Nam, T. What makes a city smart? Identifying core components and proposing an integrative and comprehensive conceptualization. Inf. Polity 2015, 20, 61-87. [CrossRef]

66. Hollands, R. Will the real smart city please stand up? Intelligent, progressive or entrepreneurial? City 2008, 12, 303-320. [CrossRef]

67. Anthopoulos, L.; Fitsilis, P. From digital to ubiquitous cities: Defining a common architecture for urban development. In Proceedings of the 2010 Sixth International Conference on Intelligent Environments (IE), Kuala Lumpur, Malaysia, 19-21 July 2010; pp. 301-306.

68. Wall, R.; Stravlopoulos, S. Smart cities within world city networks. Appl. Econ. Lett. 2016, 23, 875-879. [CrossRef]

69. Dessers, E.; Vancauwenberghe, G.; Vandenbroucke, D.; Crompvoets, J.; van Hootegem, G. Analysing spatial data performance in inter-organisational processes. Int. J. Digit. Earth 2015, 8, 403-420. [CrossRef]

70. Aykin, N. (Ed.) Usability and Internationalization of Information Technology; CRC Press: London, UK, 2016.

71. Bellini, P.; Benigni, M.; Billero, R.; Nesi, P.; Rauch, N. Km4City ontology building vs data harvesting and cleaning for smart-city services. J. Vis. Lang. Comput. 2014, 25, 827-839. [CrossRef]

72. Nesi, P.; Pantaleo, G.; Tenti, M. Geographical localization of web domains and organization addresses recognition by employing natural language processing, Pattern Matching and clustering. Eng. Appl. Artif. Intell. 2016, 51, 202-211. [CrossRef]

73. Fistola, R. Smart City: Riflessioni sull'intelligenza urbana. TeMA J. Land Use Mobil. Environ. 2013, 6, 47-60.

74. The Organisation for Economic Co-Operation and Development. Sustainable Development: Critical Issues; OECD: Paris, France, 2001.

75. Commission of the European Communities. A Sustainable Europe for a Better World: A European Union Strategy for Sustainable Development. 2001. Available online: http://europa.eu.int/eur-lex/en/com/cnc/ 2001/com2001_0264en01.pdf (accessed on 19 July 2016).

76. Shao, G.; Li, F.; Tang, L. Multidisciplinary perspectives on sustainable development. Int. J. Sustain. Dev. World Ecol. 2011, 18, 187-189. [CrossRef]

77. Springett, D. Editorial: Critical Perspectives on Sustainable Development. Sust. Dev. 2013, 21, 73-82. [CrossRef]

78. Mistretta, P.; Garau, C. Città e Sfide. Conflitti e Utopie. Strategie di Impresa e Politiche del Territorio. Successi e Criticità dei Modelli di Governance; CUEC: Cagliari, Italy, 2013.

79. Geddes, P. City Development; A Report to the Carnegie Dunfermline Trust; Irish University Press: Shannon, UK, 1904.

80. Geddes, P. Civics: As Applied Sociology; Dodo Press: Gloucestershire, UK, 1904.

81. Krieger-Boden, C. EU Cohesion Policy, Past and Present: Sustaining a Prospering and Fair European Union?; Kiel Institute for the World Economy (IfW): Kiel, Germany, 2016.

82. Regio, D.G. EU 2020 Strategy; Support in the Negotiations on the Next Period of EU Cohesion Funding (2014-2020); Country Fact Sheet: Bruxelles, Belgium, 2012. 
83. European Commission. Communication on Smart Cities and Communities European Innovation Partnership. Available online: https://www.google.it/url?sa=t\&rct=j\&q=\&esrc=s\&source=web\&cd= $2 \&$ cad=rja\&uact=8\&ved=0ahUKEwins4PHlq_PAhXLthQKHflFADQQFgglMAE\&url=https $\% 3 \mathrm{~A} \% 2 \mathrm{~F} \%$ 2Fwebapi.cor.europa.eu\%2Fdocumentsanonymous\%2FCDR589-2013_00_00_TRA_DT_EN.doc\&usg= AFQjCNG43qD3JXvQ9MWAbOnCCoR3Y2xWqw\&sig2=8CaUdhBghwXXNfUk9NDv1w (accessed on 27 September 2016).

84. European Commission. Transport in Figures. Statistical Pocketbook; Publications Office of the European Union: Luxembourg, 2012.

85. European Commission. Meeting of Advisory Group "ICT Infrastructure for Energy-Efficient Buildings and Neighbourhoods for Carbon Neutral Cities. Available online: http:/ /ec.europa.eu/information_society/ activities/sustainable_growth/docs/elsa/elsa_2010/report_elsa2010.pdf (accessed on 19 July 2016).

86. European Commission. Impact Assessment Accompanying Document to the White Paper, European Commission: Brussels, Belgium, 2011.

87. European Commission. Communication on Investing in the Development of Low Carbon Technologies (SET-Plan). Available online: http://eur-lex.europa.eu/legal-content/en/TXT/?uri=CELEX\% 3A52009DC0519 (accessed on 19 July 2016).

88. Van Soom, E. Measuring Levels of Supply and Demand for e-Services and e-Government: A Toolkit for Cities. Smart Cities Research Brief, 2009; No. 3. Available online: http://www.smartcities.info/files/Smart_ Cities_Research_Brief_Measuring_levels_of_supply_and_demand_for_eservices_and_egov.pdf (accessed on 19 July 2016).

89. Toppeta, D. The Smart City Vision: How Innovation and ICT Can Build Smart, "Liveable," Sustainable Cities. Available online: http://inta-aivn.org/images/cc/Urbanism/background\%20documents/Toppeta_Report_ 005_2010.pdf (accessed on 27 September 2016).

90. Abdulrahman, A.; Meshal, A.; Imad, F.T. A Smart Cities: Survey. J. Adv. Comput. Sci. Technol. Res. 2012, 2, 79-90.

91. Albino, V.; Berardi, U.; Dangelico, R.M. Smart cities: Definitions, dimensions, performance, and initiatives. J. Urban Technol. 2015, 22, 3-21. [CrossRef]

92. Confrontarsi per Diventare Smart. 2013. Available online: http://www.between.it/pdf/Between SmartCityIndex2013.pdf (accessed on 19 July 2016).

93. Dodgson, M.; Gann, D. Technological innovation and complex systems in cities. J. Urban Technol. 2011, 18, 101-113. [CrossRef]

94. Huggins, R.; Clifton, N. Competitiveness, creativity, and place-based development. Environ. Plan. A 2011, 43, 1341-1362. [CrossRef]

95. Garau, C.; Masala, F.; Pinna, F. Benchmarking smart urban mobility: A study on Italian cities. In Computational Science and Its Applications; Springer International Publishing: Cham, Switzerland, 2015; pp. 612-623.

96. Balletto, G.; Mei, G.; Garau, C. Relationship between Quarry Activity and Municipal Spatial Planning: A Possible Mediation for the Case of Sardinia, Italy. Sustainability 2015, 7, 16148-16163. [CrossRef]

97. Garau, C.; Masala, F.; Pinna, F. Cagliari and smart urban mobility: Analysis and comparison. Cities 2016, 56, 35-46. [CrossRef]

98. Chelleri, L.; Kua, H.W.; Rodríguez Sánchez, J.P.; Nahiduzzaman, K.M.; Thondhlana, G. Are People Responsive to a More Sustainable, Decentralized, and User-Driven Management of Urban Metabolism? Sustainability 2016, 8, 275. [CrossRef]

99. Kaletsky, A. Capitalism 4.0: The Birth of a New Economy in the Aftermath of Crisis; Perseus: New York, NY, USA, 2010.

100. Rassia, S.T.; Pardalos, P.M. Cities for Smart Environmental and Energy Futures: Impacts on Architecture and Technology; Springer: Heildeberg, Germany, 2014.

101. Birkeland, J. Design for Sustainability: A Sourcebook of Integrated, Eco-Logical Solutions; Earthscan Publications: Sterling, UK, 2012.

102. Townsend, A.M. Smart Cities: Big Data, Civic Hackers, and the Quest for a New Utopia; WW Norton \& Company: London, UK, 2013.

103. Datta, P. Patrick Geddes and the metropolis. In Cities in South Asia; Bates, C., Mio, M., Eds.; Routledge: New York, NY, USA, 2015; pp. 47-63. 
104. Khan, N. Geddes in India: Town planning, plant sentience, and cooperative evolution. Environ. Plan. D Soc. Space 2011, 29, 854. [CrossRef]

105. Rubin, N.H. Patrick Geddes and Town Planning: A Critical View; Routledge: New York, NY, USA, 2013 ; p. 55.

106. Scott, J. The social theory of Patrick Geddes. J. Class. Sociol. 2016, 16, 237-260. [CrossRef]

107. Smart Cities as Innovation Ecosystems Sustained by the Future Internet. White Paper on Smart Cities as Innovation Ecosystems. 2012. Available online: http://www.urenio.org/wp-content/uploads/2012/04/ 2012-FIREBALL-White-Paper-Final.pdf (accessed on 22 September 2016).

108. Komninos, N. The Age of Intelligent Cities; Smart Environments and Innovation for All Strategies; Routledge: London, UK, 2014.

109. Mercer, C. Geographics for the present: Patrick Geddes, urban planning and the human sciences. Int. J. Hum. Resour. Manag. 1997, 26, 211-232. [CrossRef]

(C) 2016 by the authors; licensee MDPI, Basel, Switzerland. This article is an open access article distributed under the terms and conditions of the Creative Commons Attribution (CC-BY) license (http://creativecommons.org/licenses/by/4.0/). 